\title{
Watugunung Story, a Mirror of Knowledge about the Natural Environment and Human Life Recorded in the Babad Tanah Jawi
}

\author{
Nanny Sri Lestari \\ Universitas Indonesia, Depok, Jawa barat, Indonesia, 16346, \\ nanny-sl@ui.ac.id and pbintangpagi@gmail.com
}

\begin{abstract}
This research discusses astrological knowledge known by Javanese people. The focus of this research is to trace the position of Watugunung's story in the Babad Tanah Jawi. Of course this can be achieved through a search of the Watugunung story in various Javanese texts. The purpose of this study is to raise the function and philosophical meaning of the Watugunung story recorded in the Babad Tanah Jawi. This research uses a theoretical framework of literary and environmental literature, and sign theory, to see how humans acquire knowledge and convey that knowledge and its relation to human life itself. This study uses a qualitative research paradigm procedure. The results of the study show that, in reality, humans learn about the importance of the natural environment, family and society as well as their personalities. The natural environment is the highest center of life. Humans are obliged to learn to gain knowledge to properly manage the natural environment. Knowledge of the universe with its contents, is expected to be able to build the wisdom that exists in humans. Good knowledge shows that wisdom in humans can be built through various means. One of them is through stories. Stories can be arranged based on space, time and place. Knowledge of the natural environment that is aligned with the situation and conditions of the community can be used to convey, messages of local wisdom and even messages that are in harmony, harmony and balance build awareness that a story has a very deep function and philosophical meaning. That is why the Watugunung story recorded in the Babad Tanah Jawi is a portrait of the Javanese community's efforts to convey a message to respect and maintain the natural environment well.
\end{abstract}

Keywords: Function; Natural Environment; Meaning; Society; Personal

\section{INTRODUCTION}

Folklore is a story that originates from a particular community and developed in the past and is well known today[1]. In general, folklore is a cultural heritage that provides information on people's identity and the way of thinking of society [2]. That is why there are 7 elements in the cultural elements, namely language, religion, art, livelihood, kinship system, social system, and knowledge, although later in the scientific realm researchers often disagree. Related to Watugunung's story, this story is actually a myth that has been very thick in the life of the Javanese people. The community views that this story is part of the pattern of their daily lives [3].

The basic pattern in everyday life that you want to achieve is urip tentrem kerta and raharja or peaceful, happy and peaceful life. To make it happen there are a number of things that must be heeded. First, personal conditions, namely the system of birth and inner order. Second, attitudes and behavior in interacting with family and society. Third, attitudes and behavior towards the natural environment. The third thing is the key to the safety of human life on this earth [4]. To convey this message is not easy because it must be repeated several times in several ways. For example like this 
Tabel 1. Natural environment and Human position

\begin{tabular}{ccc}
\hline $\begin{array}{c}\text { Things that must be } \\
\text { considered }\end{array}$ & Position/level & Level of human care \\
\hline $\begin{array}{c}\text { Attitudes and behavior } \\
\text { towards the } \text { natural } \\
\text { environment }\end{array}$ & Highest & $\begin{array}{c}\text { Able to understand and understand, that human life is very } \\
\text { dependent on nature and the environment where they live, both on } \\
\text { earth and in the universe. }\end{array}$ \\
\hline $\begin{array}{c}\text { Attitudes and behavior in } \\
\text { interacting with family } \\
\text { and society }\end{array}$ & Middle & $\begin{array}{c}\text { Able to understand and act, that humans in their lives can develop } \\
\text { natural and social sciences as high as possible, through various } \\
\text { means. }\end{array}$ \\
$\begin{array}{c}\text { Personal conditions are } \\
\text { physical and mental } \\
\text { conditions }\end{array}$ & Lowest & $\begin{array}{c}\text { Able to maintain and control himself in the midst of the dynamics } \\
\text { of community life (both in the family and in the community). }\end{array}$ \\
\hline
\end{tabular}

This condition requires humans to realize by taking concrete actions. The natural environment, where humans live, is a very important thing to note. Understanding the natural environment must be from the lowest point, namely understanding and controlling the human person itself which consists of lust, emotions and behavior or actions. Javanese humans must understand the understanding of this situation [5]. Knowledge of human life that must be in harmony, harmonious and balanced with the natural environment can be carried out in accordance with methods and culture[6]. The purpose of this research is to reveal the function and philosophical meaning behind this story which is full of moral and philosophical knowledge of its people.

\section{METHOD}

The natural environment, is a sign of meaningful life. The marker is the dynamics of the life of the tool itself [7]. Folklore is a living cultural monument. The Watugunung story in the Babad Tanah Jawi also has a story structure, where the elements consist of the storyline, storyline, story arrangement, story theme, message and the meaning of the story [8]. As a cultural monument this story certainly has a very high moral value.

Understanding is not easy. There is a broad knowledge to understand the local wisdom that accompanies folklore. In folklore there is also a story structure, where elements consist of storyline, storyline, story arrangement, story theme, function and meaning of the story [9]. The form of folklore passed down from generation to generation, does not have the name of the author, has many versions and variations, the expression of the story is very cliched, but behind that there are functions and philosophical meanings that are very deep.

\section{RESULT AND DISCUSSION}

\subsection{Watugunung stories in several forms}

In this discussion, the results and findings of the research are deductively, namely collecting a number of opinions from the results of research that has been done before. Javanese people have long known the tradition of writing. With this tradition of writing, Javanese society records all its activities and knowledge in a number of old manuscripts. The old text became a storehouse of endless knowledge. In this study discussed the myth of Watugunung which is part of the Babad Tanah Jawi. To complete his statement supported by the Pawukon book written by Djoko Mulyono (1993)[10] and the Primbon Betaljemur Adammakna by Soemodidjojo (2008) [11]. The Babad Tanah Jawi (or BTJ) book used in this discussion is the Babad Tanah Jawi book written by Ng. Kertapradja which has been translated and given a statement by J.J Ras (1987)[12], [13]. These three books discuss Watugunung in different positions or points of view.

Tabel 2. Watugunung story in each form

\begin{tabular}{lll}
\hline \multicolumn{1}{c}{ Title of manuscript } & Position & \multicolumn{1}{c}{ Viewpoint of discussion } \\
\hline $\begin{array}{l}\text { Watugunung story which } \\
\text { is part of the Babad Tanah } \\
\text { Jawi. }\end{array}$ & $\begin{array}{l}\text { In the } \\
\text { second part }\end{array}$ & $\begin{array}{l}\text { Being the second part of the story in the Babad Tanah Jawi, as } \\
\text { well as explaining the origin, the story of the existence of wuku } \\
\text { in Javanese knowledge. }\end{array}$ \\
\hline
\end{tabular}


of the BTJ

story

\begin{tabular}{lcl}
\hline $\begin{array}{l}\text { Watugunung story in the } \\
\text { book Pawukon }\end{array}$ & $\begin{array}{c}\text { Stand in a } \\
\text { separate book }\end{array}$ & $\begin{array}{l}\text { This book specifically contains } 30 \text { functions and meanings in } \\
\text { the repertoire of Javanese knowledge. }\end{array}$ \\
$\begin{array}{l}\text { The Watugunung story in Stand in a separate } \\
\text { book }\end{array}$ & $\begin{array}{l}\text { This book specifically contains about wuku and its relation to } \\
\text { daily life for Javanese people. The purpose of getting a happy } \\
\text { adammakna }\end{array}$ & $\begin{array}{l}\text { and peaceful life. } \\
\text { adamur }\end{array}$
\end{tabular}

From the data above, it can be seen that the position of the Watugunung story in the Babad Tanah Jawi is not the same as the position in the other two books. In the Babad Tanah Jawi the position of the Watugunung story is the second story that begins the calculation of wuku or astrology in the Babad Jawa. But the unique explanation of astrology knowledge does not appear, which is only the beginning of the appearance of wuku in Javanese society. The story of the cause of the appearance of the explanation described is rather long. Things that are very different in the other two books. The other two of us explain about the use of wuku in everyday life. Even showing the thirty wuku completely. The thirty names of the wuku are Watugunung, Sinta, Landep, Wukir, Kurantil, Tolu, Gumbreg, Warigalit, Warigagung, Julungwangi, Sungsang, Gelungan, Kuningan, Langkir, Mandhasia, Julungpujud, Pahang, Kuruwelut, Marakeh, Tambir, Madhangkungan, Maktal, Wuye, Manail, Prangbakat Bala, Wugu, Wayang, Kulawu, Dhukut.

\subsection{Function of the Watugunung story in the Babad Tanah Jawi}

On the basis of a search of the Babad Tanah Jawi, the Watugunung story is placed in the second part of the series of stories in the Babad Tanah Jawi. The function of the story explicitly does provide entertainment, but it is realized or not, a story or one that is included in a literary work besides having a function as entertainment also functions for education or knowledge, what is termed dulce et utile [14]. The Watugunung story in the Babad Tanah Jawi serves as a complement to the description of knowledge possessed by Javanese people. The names of the wuku in daily life are used as markers of human characters born at certain times. This knowledge of wuku and human character will dominate other books that discuss human life.

Tabel 3. Watugunung function in Babad Tanah Jawi

\begin{tabular}{|c|c|c|}
\hline Name of story & Position & $\begin{array}{c}\text { The function of the Watugunung story } \\
\text { in the Babad Tanah Jawi }\end{array}$ \\
\hline $\begin{array}{l}\text { Genealogy of the gods } \\
\text { inside Babad Tanah Jawi. }\end{array}$ & $\begin{array}{l}\text { First \& } \\
\text { second } \\
\text { paragraph } \\
\text { in BTJ }\end{array}$ & $\begin{array}{l}\text { Opening the story, about the origins of the gods, in the } \\
\text { genealogy of the gods. Continued with the issue of the struggle } \\
\text { for beautiful women between father and son. }\end{array}$ \\
\hline $\begin{array}{l}\text { Followed by stories of } \\
\text { problems in the Gilling- } \\
\text { wesi kingdom in the } \\
\text { Babad Tanah Jawi }\end{array}$ & $\begin{array}{l}\text { The 3rd } \\
\text { paragraph } \\
\text { to the } 25 \text { th } \\
\text { paragraph }\end{array}$ & $\begin{array}{l}\text { This paragraph contains: } \\
\text { - description of the king of Gilling-wesi who has two wives } \\
\text { namely goddess Sinta and goddess Landhep, and } 30 \text { sons of } \\
\text { both wives. } \\
\text { - description of the story of incest experienced by the goddess } \\
\text { Sinta knowing that her husband was his son who was driven } \\
\text { away. } \\
\text { - King Giling-wesi's description invades heaven and must be } \\
\text { defeated by Lord Vishnu. } \\
\text { - description of the king of Milingwesi who does not want to } \\
\text { return to earth and asks all his children to be brought to heaven } \\
\text { and because he is picked up every day for } 30 \text { times, then there } \\
\text { have been } 30 \text { wuku names since then. }\end{array}$ \\
\hline
\end{tabular}


From the data above, it can be seen that in the Babad Tanah Jawi the emphasis is on the basic issue of the emergence of the name of the 30 people. The description of the King of Millions and the situation and conditions in heaven are problems that dominate the story. The heavenly environment is the main focus besides the environment on earth.

\subsection{The philosophical meaning of the story of Watugunung in the Babad Tanah Jawi.}

One habit that is often carried out by Javanese people is to behave meticulously or be able to pay attention to something carefully and continuously. In explaining the knowledge of the world of astronomy (Javanese astronomy), Javanese people use the names of these wuku as a marker of human characters born at a certain time with all sides of good and bad.The aim is to achieve happiness and peace of life and maintain harmony in life that exists on earth and in other realms or which is often referred to as a balance between the macrocosm and the microcosm. In the case of Watugunung, the goddess Sinta learned that her son was her husband, to avoid collision, the goddess Sinta suggested that her son Watugunung invade heaven.

In the invasion Watugunung can be defeated by dewa Wisnu. Dewi Sinta requested that her husband be revived. Watugunung was indeed revived but Watugunung did not want to return to earth, even asking that all twenty-seven of his sons be appointed to heaven. Pickup is done every Ngahad day. Finally the Watugunung family was enshrined to be the name of the wuku in Javanese astrology.

From the meaning of the story, there was one incident of sin (mistake) which was done accidentally because it did not know. Errors that occur accidentally can happen to everyone, because humans must be careful in living their lives [15]. Wuku is a marker for one's character. It is hoped that by understanding the calculation of life depicted in wuku, humans are able to live in harmony with the natural environment and society.

The strong philosophical meaning in the Watugunung story of the Babad Tanah Jawi is a part of the story that involves the earth, sky and humans. Earth and sky, are two natural environments that are conveyed through this Watugunung story. Watugunung is the ruling king on earth. One time the Giling-Wesi kingdom had a big disaster, like this quote,

Kala semanten negari ing Giling-Wesi kedhatengan gegering ageng. Kathah tetiyang alit ingkang sami risak, sarta awis tedha. Asring wonten grahana srengéngé utawi grahana rembulan. Jawah salah mangsa, lindhu kaping pitu sedinten. Punika sedaya njelajati, yèn negari ing Giling-Wesi badhé risak (BTJ/7).

Translated into:

At that time the Giling-Wesi kingdom had great difficulties. Many small people were damaged (morally), and experienced food shortages. Frequent eclipses of the sun or moon. Rain is out of season, earthquakes occur seven times a day. This all shows that the Milingwesi country is heading towards destruction $(\mathrm{BTJ} / 7)$

The above quote illustrates the natural condition, which is on earth damaged by human behavior. The bad behavior can only be known in the next part, when the goddess Sinta knows who is actually Watugunung. Regret alone won't end the problem. For this reason, we need to find a way to purify ourselves by moving from the realm of birth to the inner world, with the analogy of nature being born on earth and nature being born in the sky.

\section{CONCLUSION}

The conclusion of this study is the Watugunung story is a story that conveys a message. The story message is behind the story function, which seeks to be used as a learning tool, about knowledge of local wisdom from a certain scope and time. The scope of human life, at a certain time which is limited by cultural markers.Local wisdom that carries the knowledge of the position of the human person as a lower vane layer that must synergize with family and society and the natural environment, as the highest element. Elements of the earth and celestial bodies, as well as human actions (such as unintentional mistakes) are a series of philosophical meanings to convey that humans want to respect and preserve the natural environment which is a place for humanity to live. The meaning is built from human understanding in stages and depth from one sign in events to another event. Watugunung the goddess Sinta is a figure who made a mistake accidentally. Therefore, it is necessary to re-purify 
human life to keep the natural environment from being damaged. This story invites the reader to empathize with human life and maintain the natural environment well in order to achieve a good peace of life.

\section{REFERENCES}

[1] D. James, Folklore Indonesia Ilmu Gossip, Dongeng dan lain-lain. Jakarta: Grafiti, 2002.

[2] K. Koentjaraningrat, “Antropologi Hukum,” Antropol. Indones., no. 47, Jul. 2014.

[3] H. Budiono, Simbolisme dalam Budaya Jawa. Yogyakarta: PT Hanindita, 1985.

[4] S. De Jong, Salah Satu Sikap Hidup Orang. Yogyakarta: Kanisius, 1976.

[5] F. M. Suseno, Etika Jawa: Sebuah Analisa Falsafi tentang Kebijaksanaan Hidup Jawa. Jakarta: Gramedia, 2003.

[6] A. Van Peursen, Strategi Kebudayaan. Yogyakarta: Kanisius, 1988.

[7] B. A. Arthur, Pengantar Semiotika. Yogyakarta: Tiara Wacana, 2010.

[8] M. Budiana, Husen, I. S., M. Budiman, and I. Wahyudi, Membaca sastra: pengantar memahami sastra untuk perguruan tinggi. Magelang: Indonesiatera, 2002.

[9] D. Marcel, Pesan, Tanda, dan Makna. Yogyakarta: Jalasutra, 2010.

[10] D. Mulyono, Kalender Pawukon 200 tahun 1900-2100. Jakarta: Studio Delapanpuluh Enterprise, 1993.

[11] K. Tjakraningrat, Kitab Primbon Betaljemur Adammakna. Yogyakarta: Soemodidjojo Mahadewa, 2008.

[12] N. Kertapraja and J. J. Ras, Babad Tanah Djawi. Dordrecht Holland: FORIS PUBLICATIONS, 1987.

[13] W. Hernawan, "Menelusuri Para Raja Madura Dari Masa Pra-Islam Hingga Masa Kolonial,” Wawasan J. Ilm. Agama dan Sos. Budaya, vol. 1, no. 2, pp. 239-252, Nov. 2016.

[14] J. Van Luxemburg, Pengantar Ilmu Sastra. Jakarta: Gramedia, 1992.

[15] N. Mulder, Pribadi dan Masyarakat di Jawa. Jakarta: Sinar Harapan, 1980. 